\title{
Estuarine fronts as conduits for larval transport: hydrodynamics and spatial distribution of Dungeness crab postlarvae
}

\author{
David B. Eggleston ${ }^{1, *}$, David A. Armstrong ${ }^{2}$, Ward E. Elis ${ }^{1}$, William S. Patton ${ }^{2}$ \\ ${ }^{1}$ Department of Marine, Earth and Atmospheric Sciences, North Carolina State University, Raleigh, \\ North Carolina 27695-8202, USA \\ ${ }^{2}$ University of Washington, School of Fisheries, Box 357980, Seattle, Washington 98195, USA
}

\begin{abstract}
Frontal zones are common hydrographic features in estuaries throughout the world, yet there is no consensus on the importance of fronts to larval transport processes. Frontal circulation may act as a 'barrier' to larval transport since it constrains cross-frontal flows, leading to strong along-frontal flows, which in turn may serve as a type of 'larval conduit' by funneling larvae collected at the front to settlement locations. We examined the larval conduit hypothesis by characterizing hydrodynamic features of apparent frontal structure in Grays Harbor estuary (Washington, USA) and quantifying the effects of frontal structure on the distribution and transport potential of Dungeness crab Cancer magister megalopae dunng spring-time recruitment pulses. CTD casts made perpendicular to fronts indicated that frontal structure was characteristic of buoyant plume and axial convergent fronts at the bay mouth and at a subtidal channel site within the estuary, respectively. Surface drifters deployed seaward of a front at the bay mouth during early flood tide were advected into the front, demonstrating convergent circulation. Surface drifters remained within buoyant plume fronts, which moved up-estuary during flood tide at $0.4 \mathrm{~m} \mathrm{~s}^{-1}$, and were then entrained in axial convergent fronts. Drifters moved an average of $10 \mathrm{~km}$ up-estuary during a single flood tide; the direction that drifters tracked corresponded to prevailing winds. The mean concentration of megalopae, as measured with neuston nets, was significantly higher in fronts than in adjacent water, 20 to $30 \mathrm{~m}$ upstream of the front, irrespective of year or location within the estuary. Paired plankton nets deployed at the bay mouth during flood tide indicated that the mean concentration and flux of megalopae was higher at the surface than at 3 to $4 \mathrm{~m}$ depth; this trend was significant for megalopal flux. Variable wind stress during the recruitment period of Dungeness crab, combined with the suggested effect of fronts serving as larval conduits whose direction of transport is influenced by prevailing winds, could significantly influence spatial variation in postlarval supply and subsequent settlement within the estuary.
\end{abstract}

KEY WORDS: Cancer magister D Drifters Dungeness crab Estuarine hydrodynamics F Fronts - Larval transport Recruitment

\section{INTRODUCTION}

Estuarine frontal systems, typically distinguished by striking changes in water color and foam lines containing floating debris and high concentrations of organisms, are commonly observed in estuaries throughout the world. Estuarine fronts are usually associated with density differences between 2 water layers leading to convergence at the surface or bottom boundary, which maintains the front as a sharp transition or interface.

•E-mail:eggleston@ncsu.edu even in the presence of diffusive effects (Largier 1992, O'Donnell 1993). Fronts characterized by strong surface convergence result in the accumulation of surface debris, foam and surfactants along the plunge line. Organisms that are buoyant or tend to swim upward in the water column may form dense accumulations in the surface within the frontal zone. Increased awareness of the presence and ecological role of fronts is critical to understanding estuarine larval transport processes, as well as to the proper design of biological sampling programs and ecological experiments, since frontal systems can redistribute food, change predator behavior, 
and alter pelagic habitats such as drifting macroalgae and gelatinous zooplankton (Kingsford 1993).

Numerous studies have documented how frontal circulation influences both the distribution and movement of pre-settlement stages of crustaceans and fish in estuarine and nearshore environments (Zeldis \& Jillett 1982, Shanks 1983, 1986, Kingsford \& Choat 1986 , Epifanio 1987, Shanks \& Wright 1987, Roughgarden et al. 1988, Clancy \& 1989, Farrell et al. 1991, Kingsford et al. 1991, Kingsford 1993, Kingsford \& Suthers 1994, Pineda 1994). For example, larvae of the intertidal crab Pachygrapsus crassipes were carried onshore in surface fronts generated by tidally driven internal waves, which suggests that such a process may be an important mechanism for onshore transport of planktonic stages of some marine benthic organisms (Shanks 1983). Similarly, high concentrations of blue crab Callinectes sapidus postlarvae were collected in fronts in Delaware Bay, USA (Clancy \& Epifanio 1989). Conversely, Pickney \& Dustan (1990) tested and rejected the hypothesis that frontal zones in Charleston Harbor, USA, contain higher concentrations of phytoplankton and zooplankton than adjacent waters upstream of the front. Despite the prevalence of estuarine fronts, there is currently no consensus on the ecological role or importance of fronts to larval transport (Largier 1993).

Frontal circulation may act as a 'barrier' to the widespread dispersion of larvae, thereby controlling recruitment to benthic populations (Roughgarden et al. 1988, Farrell et al. 1991). The frontal barrier may be purely physical - passive drifters are retained on one side or the other (Franks \& Anderson 1992) - or the barrier may reflect habitat demarcation, with particular species preferring one side over another (Graham 1993). Since fronts constrain cross-frontal flow, they serve to deflect incident flow resulting in strong alongfrontal and downwelling flows that transport larvae collected at the front (Largier 1993). Thus, for strongswimming larvae that maintain themselves in surface waters, fronts may also serve as 'larval conduits' since these larvae are likely to settle where the front intersects adequate settlement habitat. If the front is anchored by a topographic feature, then this settlement intersection will tend to be either a single, stationary end-point or a line along the benthic axis of the front. Furthermore, the importance of fronts in determining settlement patterns will likely depend upon the longevity of the front, as well as the strength of the flows and larval abundance.

The overall goal of this study was to characterize hydrodynamic features of apparent frontal structure in a tidally driven estuary and quantify the effects of frontal structure on larval distribution and transport. Specifically, we addressed 4 main questions. (1) What is the physical structure of observed fronts, and does this structure vary according to location within the estuary? (2) How does wind direction and the presence of fronts influence near-surface transport? (3) Are concentrations of larvae higher inside than outside of fronts? (4) What is the vertical distribution of larvae during the passage of fronts at flood tide?

\section{Dungeness crab life history}

Dungeness crab Cancer magister is a dominant, highly motile benthic marine invertebrate of shallow coastal and estuarine habitats along the north Pacific coast of North America. Its complex life history is characteristic of marine invertebrates with a broadcast reproductive strategy and meroplanktonic larvae. Along the Washington coast, larvae are released during January and proceed through 5 zoeal stages over a period of 130 to $150 \mathrm{~d}$ (Lough 1976). The larvae are planktonic in ocean waters and may be transported hundreds of kilometers during this life history phase (McConnaughey et al. 1992). The last larval stage then metamorphoses into the megalops stage (= postlarva) in nearshore waters. The megalopa's behavior, morphology and physiology is transitional between the larval and early juvenile stages (Poole 1966, Brown \& Terwilliger 1992). In coastal waters, megalopae may remain at the surface (Reilly 1983), in deeper water (Lough 1976), or occupy the neuston at night and migrate to deeper water during the day (Hobbs \& Botsford 1992). Before the spring transition in prevailing wind direction along the Oregon and Washington coasts, Ekman transport (i.e. wind-driven circulation as a function of wind stress) is landward by virtue of prevailing southwesterly winds, and this landward surface transport presumably retains megalopae positioned in near-surface waters close to shore and directs them towards estuaries (McConnaughey et al. 1992). Actively swimming megalopae then enter coastal and estuarine waters primarily during May-June (Gunderson et al. 1990), and metamorphose into first instar juveniles (J1) after settlement in subtidal and intertidal habitats. Dungeness crab is an excellent species for examining the influence of estuarine fronts on larval transport in estuaries because it is large (ca $5 \mathrm{~mm}$ length) and can be easily collected in the neuston, resides in surface waters under downwelling conditions, and often exhibits predictable settlement pulses.

\section{MATERIALS AND METHODS}

Study system. Field observations and measurements were conducted in Grays Harbor, a drowned river estuary characterized by expansive mudflats and a 
series of intervening channels, located on the Washington coast of North America $\left(47^{\circ} \mathrm{N}, 124^{\circ} \mathrm{W}\right.$; Fig. $\left.1 \mathrm{~A}\right)$. The estuary is approximately $24 \mathrm{~km}$ long and $18 \mathrm{~km}$ wide, with a water surface area ranging from $146 \mathrm{~km}^{2}$ at mean high water to $61 \mathrm{~km}^{2}$ at mean low water. Grays Harbor is a well-mixed estuary with tidally driven circulation and strong spring tidal currents averaging $0.4 \mathrm{~m} \mathrm{~s}^{-1}$. Tides in the region are semi-diurnal. Tidal currents are strongest during spring tides associated with full and new moons and during periods of greatest tidal amplitudes, especially during May through July and November through January. We have observed swarms of Dungeness crab megalopae concentrated along convergent zones of tidal intrusion fronts located near the entrance to the estuary (e.g. bay mouth; Fig. 1A), and along the interface between extensive intertidal areas and adjacent channels (e.g. 'mid-bay', 'South Channel' and 'Pacman'; Fig. 1A) during new moon, daytime flood tides in May and June (Eggleston \& Armstrong 1995). Tidal intrusion fronts that typically originate near the bay mouth (Fig. 1A) appear indicative of buoyant plume fronts that form as inflowing dense seawater plunges beneath buoyant estuarine water (e.g. Fig. 10 in Largier 1992). Conversely, fronts that set up in subtidal channels at 'South Bay' and South Channel areas (Fig. 1) appear indicative of axial convergent fronts (O'Donnell 1993). Axial convergent fronts are shear fronts that form as dense seawater intrudes rapidly in mid-channel during flood tide (Nunes \& Simpson 1985). In certain circumstances, a buoyant plume convergence can connect to an axial convergent front that continues up-estuary, thus providing a conduit for larval transport.

Frontal structure, convergence, near-surface velocity and tidal excursion. Hydrographic measurements were taken twice during spring, flood tides in May and June 1992 to characterize the physical structure of estuarine fronts at the bay mouth and in a subtidal channel at the 'South Bay' area of Grays Harbor (Fig. 1A). Hydrographic measurements were conducted simultaneously with plankton sampling (see 'Postlarval sampling procedure and design' below). We hypothesized that fronts at the bay mouth and subtidal channel were buoyant plume and axial convergent fronts, respectively. Hydrographic measurements consisted of 5 equidistant CTD casts made along a $100 \mathrm{~m}$ transect perpendicular to a front. The mid-point of each transect was in the front line, and each transect extended $50 \mathrm{~m}$ to either side of the front line. A Beckman RS-5 CST meter was used to measure vertical and horizontal changes in salinity and temperature. A contour plot of the vertical distribution of temperature, salinity and density $\left(\sigma_{1}\right)$ was made along each transect, and this internal structure was compared with idealized internal structures for buoyant plume and axial convergent fronts shown in O'Donnell (1993) and Nunes \& Simpson (1985), respectively. Densities were calculated from salinity and temperature data according to Knauss (1978). Contour plots of hydrographic structure were constructed with standard box-averaging methods using 4 adjacent points; plots were generated using the 'smooth' function within IDL software (Interactive Data Language 1995).

We examined convergence in fronts, near-surface velocity, and the extent of flood-tide excursion by tracking replicate surface drifters under different wind conditions during May-June 1993. We used the socalled 'CODE' surface drifter because its mean velocity closely approximates Lagrangian mean velocity (Davis et al. 1982). A replicate drifter measurement consisted of releasing 2 drifters, located approximately $30 \mathrm{~m}$ apart, simultaneously at the bay mouth (Fig. 1) during the beginning of flood tide, and tracking them until slack high tide $(-4 \mathrm{~h})$, or until they became grounded. Drifters were tracked visually after release from a $6 \mathrm{~m}$ boat, and their location recorded every 30 min during flood tide $(\sim 4$ h) with a hand-held Loran-C positioning system. Five replicate releases were conducted during May and June under variable wind conditions during strong spring tides.

Postlarval sampling procedure and design. We used 2 techniques to measure concentrations of Dungeness crab megalopae during new moon settlement pulses: neuston nets, which sampled megalopae within or outside of fronts, and paired plankton nets moored from a stationary boat, which measured vertical distribution of megalopae during the passage of fronts. Although both techniques targeted planktonic megalopae, we differentiate between neuston and plankton nets based on net configuration and deployment.

Spatial distribution of megalopae measured with neuston nets: Megalopae in the neuston were sampled by positioning a dip net $(36 \mathrm{~cm} \times 36 \mathrm{~cm} \times 2 \mathrm{~mm}$ mesh; equivalent to a neuston tow) in the water surface ( 0 to $40 \mathrm{~cm}$ deep) at the bow of a small boat $(6 \mathrm{~m})$, and pushing it for 2.5 min through the center of a front or in adjacent rippled waters 20 to $30 \mathrm{~m}$ upstream from a front. The use of a hand-held neuston (dip) net allowed us to sample directly along the center of a front, regardless of the degree to which it meandered. Moreover, by pushing the net rather than towing it we avoided disrupting a patch of megalopae with the boat and propeller. Three daily replicate neuston measurements were taken within a front and in adjacent waters upstream of a front during recruitment pulses of Dungeness crab in May 1992 and 1994. During each sampling period, we randomly chose to sample at one of 3 potential areas in Grays Harbor where fronts had been consistently observed: bay mouth, mid-channel, and South Channel (Fig. 1). In 1992, neuston samples were 

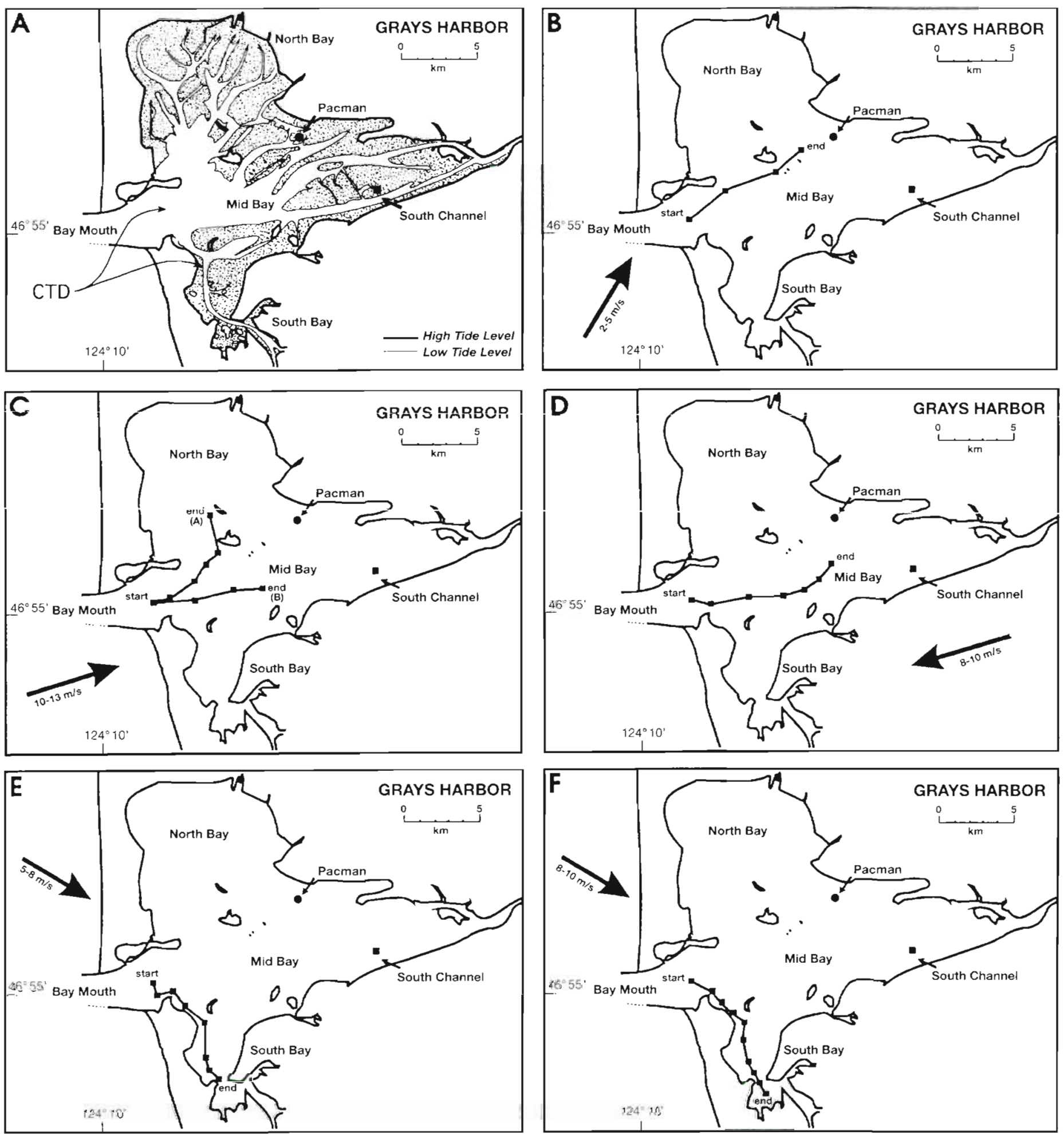

Fig. 1. (A) Study sites in Grays Harbor, Washington, USA. Stippling indicates intertidal habitats at mean low water. The locations of CTD measurements at the bay mouth and South Bay sites are identified with arrows. (B-F) Directions and distances traveled by surface drifters ( $N=2$ per day) under different wind directions (indicated by arrow) and speeds during new moon spring tides in May and June 1992. Drifters were released $30 \mathrm{~m}$ apart, always at the same location in the bay mouth, during early flood tide, and tracked by a small boat for $\sim 4 \mathrm{~h}$. Drifter locations were identified every half-hour with a hand-held Loran-C positioning

system. With the exception of $\mathrm{C}$, a single track-line illustrates the tracks of 2 drifters that were within $-10 \mathrm{~m}$ of each other 
taken at South Channel, whereas in 1994 samples were taken at the bay mouth. A replicate neuston measurement consisted of the average of 4 pooled neuston samples taken in and out of a single front during a daytime flood tide. Since fronts completely dissipated during an entire ebb tidal cycle, we viewed each daily series of flood-tide neuston measurements as an independent replicate.

Neuston nets (dip nets) were equipped with a flowmeter (General Oceanics model 2030); water volumes filtered per sample ranged from 1.8 to $6.4 \mathrm{~m}^{3}$. The number of megalopae was recorded after each net push and standardized as the mean number of megalopae per $\mathrm{m}^{3}$. The mean concentration of megalopae collected in fronts versus outside of fronts for a given sample location and year was contrasted with a paired $t$-test. Concentrations of megalopae were transformed as natural $\log$ of $(x+1)$ when necessary to standardize variances.

During 1992, we also characterized how concentrations of megalopae varied according to tidal stage. Neuston measurements were taken in fronts during flood and early-ebb tidal stages at the bay mouth on May 1, 1992, and at South Channel on May 2, 1992. During the early stages of flood tide (first hour) fronts were still visible and could be sampled in a manner similar to that used during flood tides. Although fronts were sampled at different tidal stages, there was no replication of ebb-tidal stages. Thus, we limited our presentation of results to a tabular portrayal.

Vertical distribution of megalopae measured with plankton nets: Paired plankton nets $1 \mathrm{~m}$ apart were moored for 1 to $2 \mathrm{~h}$ off the bow of a small boat $(7 \mathrm{~m})$ that was anchored at the bay mouth during 2 separate daytime flood tides in May 1997. Each net contained $0.5 \mathrm{~mm}$ mesh, and filtered an area $50 \mathrm{~cm}$ wide by $100 \mathrm{~cm}$ in height $\left(0.5 \mathrm{~m}^{2}\right)$. Paired nets were simultaneously deployed at the surface (0 to $50 \mathrm{~cm}$ deep) and at 3 to $4 \mathrm{~m}$ depth. We chose a depth of 3 to $4 \mathrm{~m}$ because CTD measurements in 1992 indicated that the pycnocline occurred at this depth (Fig. 2). Each net was equipped with a flow-meter; water volumes filtered per sample ranged from 483 to $784 \mathrm{~m}^{3}$. Although filtration efficiency for plankton nets of the same design (but with $1 \mathrm{~mm}$ mesh) was approximately $90 \%$ for blue crab Callinectes sapidus megalopae in Chesapeake Bay, USA (Olmi 1994), we do not know whether or not net avoidance by strong-swimming Dungeness crab megalopae was a problem in this study. Nevertheless, our primary goal was to compare relative rates of postlarval concentration and flux between surface and mid-water depths, and so we assumed that the plankton nets provided valid measurements for statistical comparisons between depths. Collections were standardized as one of 2 response variables: (1) megalopal concentration (megalopae $\mathrm{m}^{-3}$ ), which was the daily mean number of megalopae per cubic meter of water sampled for the paired net samples; and (2) megalopal flux (megalopae $\mathrm{h}^{-1} 0.5 \mathrm{~m}^{-2}$ ), which was simply the daily mean number of megalopae through a vertically arranged $0.5 \mathrm{~m}^{2}$ area during $1 \mathrm{~h}$ of peak flood tide. Megalopal concentration provides a more traditional measure of postlarval supply by describing the concentration of megalopae passing over a fixed area of bottom at a given time, whereas megalopal flux provides a measure of the total number of megalopae passing over an area at a given depth during a fixed amount of time. Each response variable was contrasted between surface and mid-depth with a paired $t$-test.

\section{RESULTS}

\section{Frontal structure}

At the bay mouth site, dense seawater was located offshore of the front, and appeared to plunge beneath a layer of estuarine water at depths of 4 to $5 \mathrm{~m}$ (Fig. 2). Highly variable isopycnals, with sharply increasing salinity and density values and decreasing temperature values, occurred at depths of 2 to $6 \mathrm{~m}$, and appeared concentrated in a horizontal band that was approximately $15 \mathrm{~m}$ on either side of the mid-point of the front (Fig, 2). The physical characteristics of this front were typical of buoyant plume estuarine fronts (Largier 1992). Apparent buoyant plume fronts observed in the bay mouth during strong, spring tides were approximately 1 to $2 \mathrm{~km}$ in length and oriented in a north-south direction.

Frontal structure at the South Bay, subtidal channel site (Fig. 1) was indicative of an axial convergent front (Nunes \& Simpson 1985). In this case, the center of the subtidal channel contained relatively low temperature, high salinity and density seawater surrounded on either side by estuarine water (Fig. 3). Rapidly changing isopycnals were concentrated in a horizontal band that was approximately $10 \mathrm{~m}$ on either side of the midpoint of the front (Fig. 3). The axial convergent fronts observed during spring tides in subtidal channels in Grays Harbor typically extended most of the length of a particular subtidal channel ( 10 to $15 \mathrm{~km}$ in length), and were oriented N-S or E-W depending upon the long axis of a particular channel.

\section{Convergence, near-surface velocity and tidal excursion}

In all cases, surface drifters deployed approximately $100 \mathrm{~m}$ seaward of a front at the bay mouth during early flood tide were advected into the front, thereby 
(a) Temperature

(b) Salinity

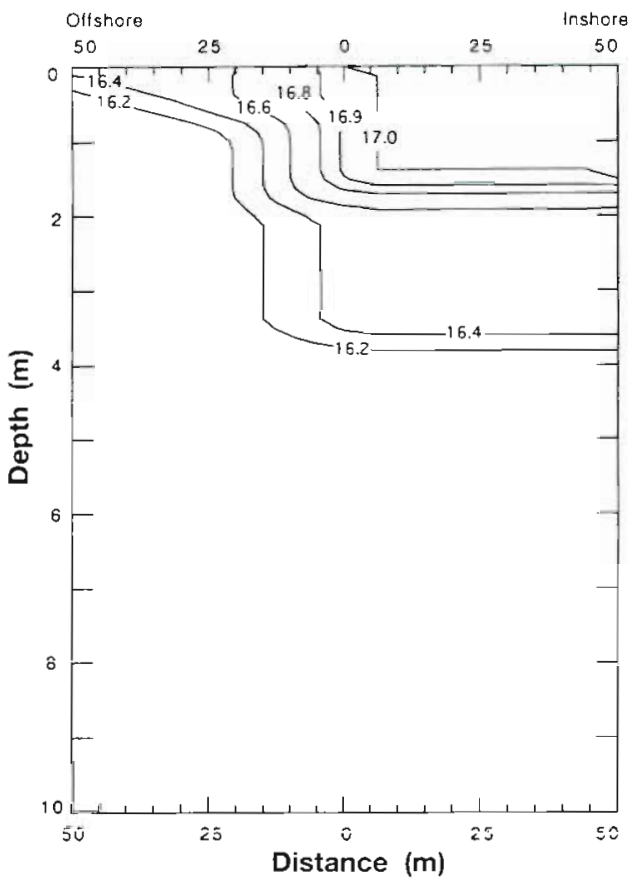

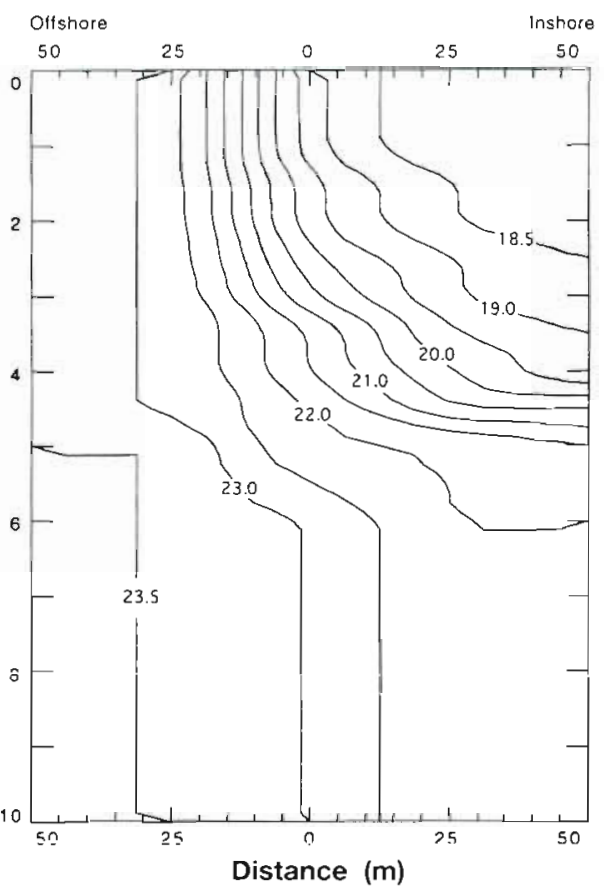

(c) Sigma-t

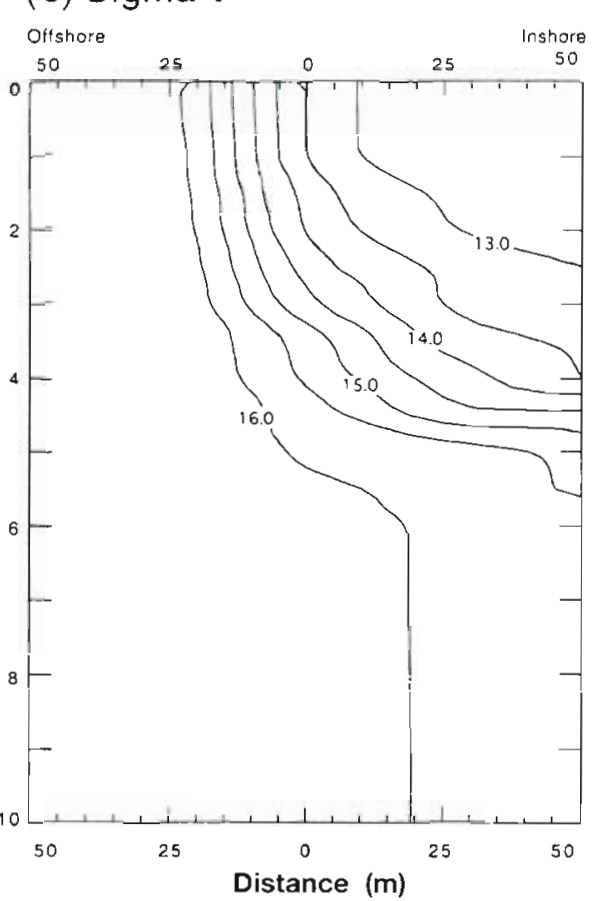

Fig. 2. Physical structure of a front at the bay mouth site as measured by CTD casts along a 100 m transect perpendicular to the front during flood tide. (a) Temperature, (b) salinity and (c) $\sigma$-t values

(a) Temperature

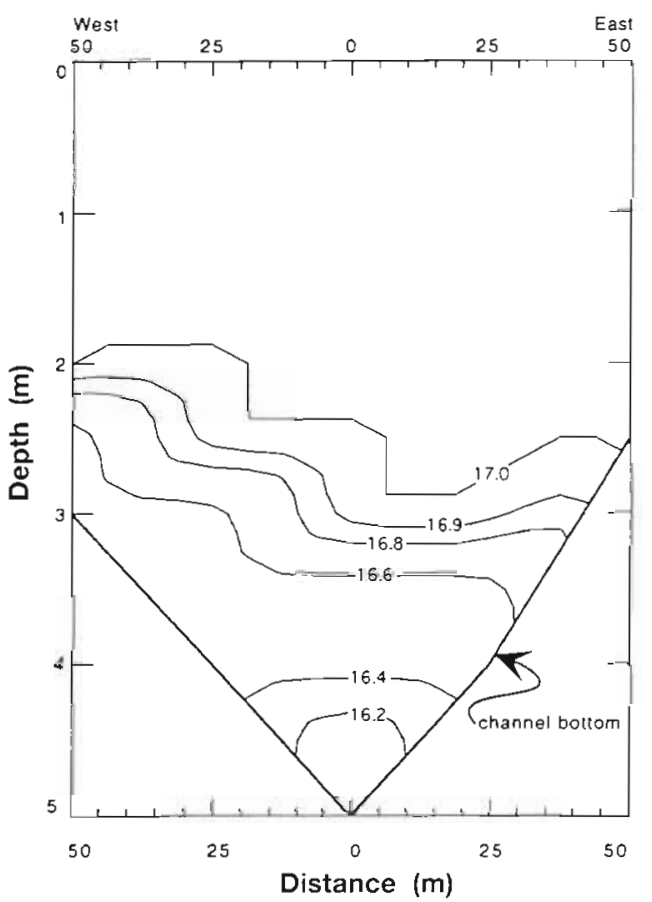

(b) Salinity

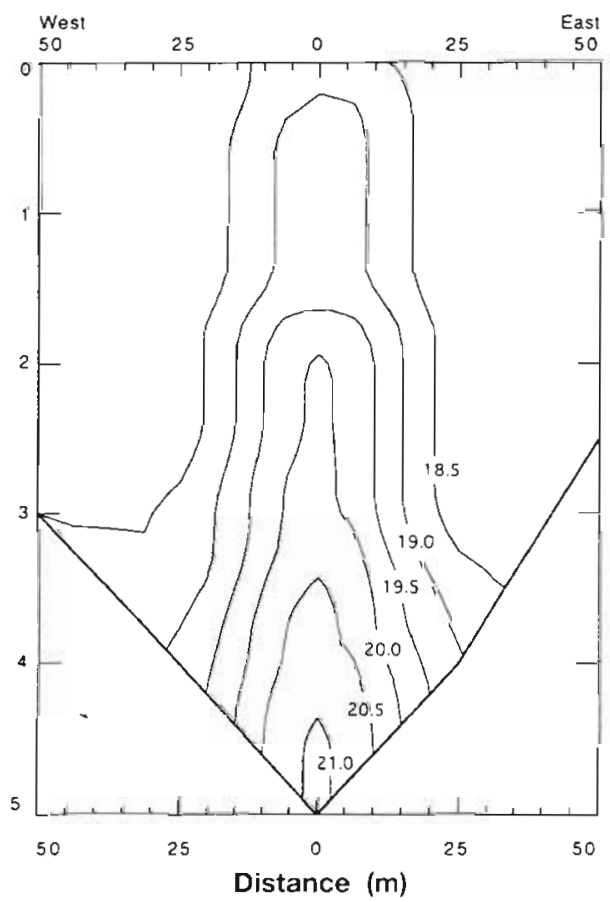

(c) Sigma-t

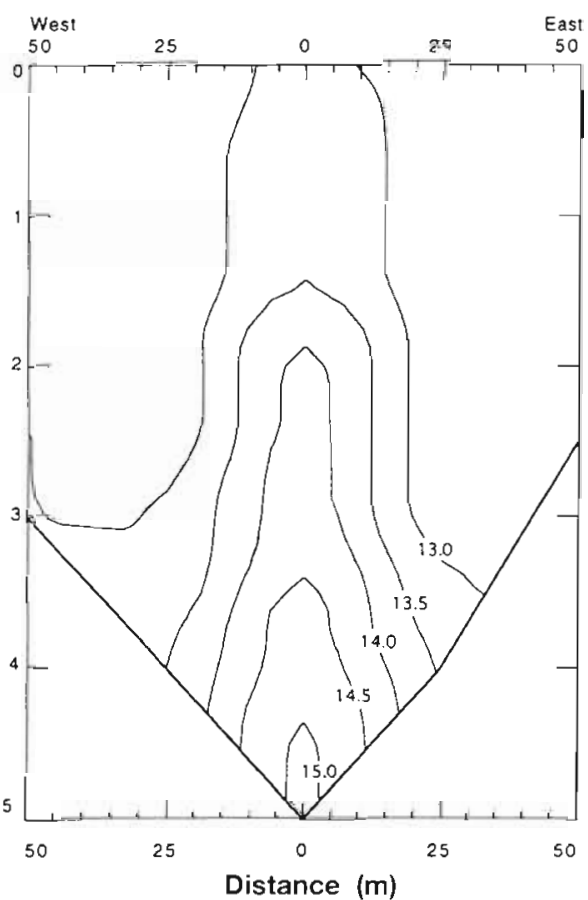

Fig. 3. Physical structure of a front at the 'South Bay' site as measured by CTD casts along a 100 m transect perpendicular to the front during flood tide; the front was oriented N-S. (a) Temperature, (b) salinity, and (c) $\sigma$-t values 
demonstrating convergent circulation. Surface drifters remained within buoyant plume fronts, which moved up-estuary during flood tide at speeds of approximately $0.4 \mathrm{~m} \mathrm{~s}^{-1}$, and were then entrained in axial convergent fronts in subtidal channels (Fig. $1 B$ to F). The drifters continued to move up-estuary within axial convergent fronts at flood-tide speeds; they moved an average of $10 \mathrm{~km}$ up-estuary during a single flood tide. Thus, megalopae acting simply as passive particles in surface waters could easily be transported from the bay mouth to intertidal settlement and early juvenile nursery habitats during a single flood tide (compare intertidal habitats shown in Fig. 1A with drifter tracks in Fig. $1 \mathrm{~B}$ to F). Moreover, the direction of drifter tracks was influenced by prevailing northwesterly and southwesterly winds. For example, during northwesterly winds of 5 to $10 \mathrm{~m} \mathrm{~s}^{-1}$, drifters consistently tracked to the south (Fig. 1E, F). Similarly, during southwesterly and westerly winds of 2 to $13 \mathrm{~m} \mathrm{~s}^{-1}$, drifters tracked to the northern and central portions of the estuary (Fig. 1B, C). A set of drifter tracks during a single flood tide with westerly winds (Fig, 1C) was the only instance where the 2 drifters did not stay within $10 \mathrm{~m}$ of each other. On a single day with easterly winds, both drifters moved up the central portion of the estuary. Despite traveling against the prevailing easterly winds, the drifters moved an equivalent distance to those deployed when winds were normal to the direction of the flood tide (compare the distances moved in Fig. 1D versus Fig. 1B, C, E, F). The drifter tracks during easterly winds were the only occasions when the drifters did not remain within foam lines.

\section{Spatial distribution of megalopae in relation to fronts}

The mean concentration of megalopae at the bay mouth in 1994 was significantly higher in fronts than outside of fronts (Table 1; paired $t$-test: $t=2.91, \mathrm{df}=2$, $p=0.04$ ). Similarly, the mean concentration of megalopae at South Channel in 1992 was significantly

Table 1. Cancer magister. Mean concentration (no. $\mathrm{m}^{-3}$ ) of megalopae ( $\pm 1 \mathrm{SE}$ ) measured with neuston nets $(0$ to $40 \mathrm{~cm}$ depth) pushed through the center of a front as a function of tidal stage at the bay mouth and South Channel sites. $N=3$ during flood tides; $N=1$ during ebb tides. See text for significance levels for flood-tide comparisons

\begin{tabular}{|lrcc|}
\hline $\begin{array}{l}\text { Estuarine } \\
\text { location }\end{array}$ & \multicolumn{4}{c}{$\begin{array}{c}\text { Location relative to front } \\
\text { In front } \\
\text { (flood tide) }\end{array}$} & $\begin{array}{c}\text { In front } \\
\text { (ebb tide) }\end{array}$ & $\begin{array}{c}\text { Outside front } \\
\text { (flood tide) }\end{array}$ \\
\hline Bay mouth & $10.76(2.60)$ & $2.50(0.50)$ & $0.66(0.10)$ \\
South Channel & $2.78(1.00)$ & $0.50(0.10)$ & $0.05(0.04)$ \\
\hline
\end{tabular}

higher in fronts than adjacent waters 20 to $30 \mathrm{~m}$ upstream of a front (Table 1; paired $t$-test: $t=9.05, \mathrm{df}=2$, $\mathrm{p}=0.0001)$.

\section{Qualitative observations of megalopal abundance in relation to tidal stages}

The mean concentration of megalopae collected in fronts with neuston nets at the bay mouth was over 3 times higher during flood than ebb tide (Table 1). Similarly, the concentration of megalopae at South Channel was 5 times higher during flood tide than ebb (Table 1).

\section{Vertical distribution of megalopae}

Paired plankton nets at the bay mouth indicated that the mean concentration and flux of megalopae was 6 to 20 times greater, respectively, at the surface than at 3 to $4 \mathrm{~m}$ depth (Table 2 ). This trend in vertical distribution of megalopae was significant for the flux of megalopae (paired $t$-test: $t=12.7, \mathrm{df}=1, \mathrm{p}=0.049$ ) but not megalopal density $(t=8.11, \mathrm{df}=1, \mathrm{p}=0.078)$.

Table 2. Cancer magister. Vertical distribution of megalopal density. Mean concentration (no. $\mathrm{m}^{-3}$ ) and flux (no. $\mathrm{h}^{-1} 0.5 \mathrm{~m}^{-2}$ ) of megalopae ( $\pm 1 \mathrm{SE}$ ) measured with paired plankton nets at the bay mouth during flood tide as a function of location within the water column. $N=2$. See text for significance levels

\begin{tabular}{|c|c|c|}
\hline \multirow{2}{*}{$\begin{array}{l}\text { Megalopal } \\
\text { density }\end{array}$} & \multicolumn{2}{|c|}{ Vertical location within water column } \\
\hline & Surface & Mid-depth \\
\hline Concentration & $1.62(0.15)$ & $0.08(0.04)$ \\
\hline Flux & $115.5(28.5)$ & $20.0(7.0)$ \\
\hline
\end{tabular}

\section{DISCUSSION}

The results from this study suggest that there are 2 dimensions and phases of estuarine fronts during a particular spring tidal excursion in Grays Harbor. Tidally induced fronts propagate $W$ to $E$ into Grays Harbor at about $0.4 \mathrm{~m} \mathrm{~s}^{-1}$ during flood tide and are oriented N-S in their long axis, and high concentrations of megalopae occur at frontal boundaries during springtide settlement pulses of Dungeness crab. These frontal features typically range in length from 1 to $2 \mathrm{~km}$. In this scenario buoyant plume fronts may or may not serve as 'barriers' to megalopal transport normal to the front. Once within the mid-estuary, where water depths rapidly become shallow $(10 \mathrm{~m})$, fronts may alter to become axial convergent fronts whose ori- 
entation is either $\mathrm{N}$-S or E-W depending upon the long axis of the subtidal channel, but may be substantially influenced in direction by wind shear that during the study was most significant (relative to megalopal transport) when winds blew from the southwest or northwest to direct these fronts into North or South Bays, respectively (Fig. 1). In this scenario, axial convergent fronts may serve as a type of 'larval conduit' delivery system, wherein plankton move along the front at flood-tide speed and may or may not cross it. The principal months that Dungeness crab megalopae enter Grays Harbor (May and June) coincide with a spring transition in predominant wind direction, when winds shift from southwesterly to northwesterly (McConnaughey et al. 1992). Variable wind stress during the recruitment period of Dungeness crab, combined with the effect of fronts serving as a larval conduit whose direction of transport is influenced by prevailing winds, as suggested by the data from this study, could significantly influence spatial variation in postlarval supply and subsequent settlement within the estuary. Our previous examination of Dungeness crab recruitment in Grays Harbor indicated that postlarval supply to intertidal settlement habitats was high when fronts intersected these habitats and that megalopal density and flux corresponded to wind speed and direction (Eggleston \& Armstrong 1995). Moreover, the density of early juvenile Dungeness crabs residing in intertidal habitats was correlated positively with postlarval supply (Eggleston \& Armstrong 1995).

\section{Mechanism for the accumulation of megalopae in fronts}

Strong-swimming planktonic animals often form dense aggregations along oceanic fronts because they are not under the influence of ambient vertical flow velocities (Franks \& Anderson 1992 and references therein). Dungeness crab megalopae are extremely strong swimmers (forward movement against a flow of $0.4 \mathrm{~m} \mathrm{~s}^{-1}$ and $12 \mathrm{~m} \mathrm{~s}^{-1}$ in still water; Fernandez et al. 1994) and, according to Franks \& Anderson's (1992) model of steady, 2-dimensional cross-frontal circulation, they were probably compressed by the horizontal flows associated with this type of convergent front and concentrated along the pycnocline between high saline oceanic water as it plunged below less saline estuarine water. Dungeness crab megalopae entrained in fronts in Grays Harbor were typically observed swimming against the current. Convergent surface currents can carry organisms from either side of a front to the region of downwelling. Swimming against the current would prevent megalopae from being downwelled to deeper depths, and simultaneously allow megalopae to be transported up-estuary during flood tide. Although downwelling at frontal zones may not be a stimulus for upward larval swimming behavior, several laboratory studies have demonstrated that brachyuran crab larvae exhibit upward swimming behavior under the type of downwelling conditions which occur at tidal fronts (see Sulkin 1984 and references therein). Moreover, we found that the mean concentration and flux of megalopae was 6 to 20 times greater, respectively, at the surface than at 3 to $4 \mathrm{~m}$ depth. Conversely, brachyuran crab larvae sampled along estuarine fronts in Delaware Bay were consistently found below the pycnocline in dense seawater (Clancy \& Epifanio 1989). Clancy \& Epifanio (1989) postulated that the greater abundance of crab larvae below the pycnocline in Delaware Bay was due to the often deep distribution of advanced zoeal stages of many estuarine species of crab whose behavior favors retention within the estuary (see Sandifer 1975), rather than export and eventual return.

Our unreplicated neuston measurements during different tidal stages suggest that concentrations of Dungeness crab megalopae in the surface are dramatically higher during flood tide than ebb. These observations are consistent with predictions based on selective tidal-stream transport up-estuary (De Vries et al. 1994, Olmi 1994). This mechanism involves rhythmic increases in swimming activity of megalopae such that they ride flood-tide currents in surface waters, and then return to or near the bottom on ebb tides (e.g. De Vries et al. 1994, Olmi 1994 and references therein). The hypothesis of vertical migration based upon tidal rhythm (shallow at flood, deep at ebb) suggested by Carriker (1951) has been confirmed for larvae of the xanthid crab Rhithropanopeus harrisii (Cronin \& Forward 1983); the blue crab Callinectes sapidus (Epifanio et al. 1984, De Vries et al. 1994, Olmi 1994); and the penaeid shrimp Penaeus duorarum. Blue crab megalopae in Delaware Bay were virtually absent from the water column during ebbing tide but were found concentrated at various depths during flooding tide (Epifanio et al. 1984). In shallow regions near the mouth of Grays Harbor, transport up-estuary would be enhanced if Dungeness crab megalopae remained on the bottom during ebb tide and re-entered the water column during flood tide. Such a selective tidal stream transport mechanism for Dungeness crab megalopae would likely operate irrespective of the presence or absence of fronts. Further measurements are needed to define the relative importance of vertical migration behavior on transport and settlement patterns of Dungeness crab megalopae, since an alternative explanation for the observed paucity of megalopae in fronts during ebb tide may be the lateral diffusion of the convergence (i.e. dilution of the front) during ebb tide. 
Neuston measurements of Dungeness crab megalopae, which were replicated in time and space, indicated that convergent velocities associated with estuarine fronts in Grays Harbor are sufficient to collect buoyant and upward-swimming plankton at the surface. Whether or not the buoyant plume fronts often observed at the bay mouth serve as a barrier to larval transport normal to the front is unknown. For a front to serve as a true barrier that precludes cross-frontal larval exchange, it must not only persist in time but it must also extend from top to bottom and from side to side (e.g. within a channel). In many cases, a front forms a barrier only in mid-channel or near surface, with substantial exchange occurring along the boundaries or at depth (Largier 1993). Nevertheless, our measures of the vertical distribution of megalopae suggest that the majority of megalopae are concentrated in surface waters, and, if drifter trapping by fronts approximates trapping of megalopae, buoyant plume fronts may at least serve as a partial barrier to transport of megalopae normal to the front. The notion of estuarine fronts as possible barriers and eventual conduits for estuarine transport of larvae to settlement 'hat spots' could have important population-level consequences for a given cohort or year class of Dungeness crab, particularly given the highly cannibalistic nature of this species (Fernandez et al. 1993). In conclusion, the findings from this study promote the development of more realistic conceptual and mathematical models of recruitment processes that combine 3-dimensional hydrographic frontal circulation and local wind-forcing, with vertical distribution of larvae, to better understand the bio-physical processes underlying spatial variation in postlarval supply and settlement.

Acknowledgements. We thank K. Feldman, G. Williams, and $S$. Brooke for field assistance; F. Bignami and T. McKellar for producing the contour plots of frontal structure, and $B$. Hickey and 4 anonymous referees for critical reviews. This work was funded by a University of Washington, College of Ocean and Fishery Science postdoctoral fellowship to D.B.E., institutional grants from Washington Sea Grant (NA36RG0071-01 and NA76RG0119, Project R/ES-19), Sigma Xi support to $S$. Brooke, and research support from North Carolina State University.

\section{LITERATURE CITED}

Brown AC, Terwilliger NB (1992) Developmental changes in ionic and osmotic regulation in the Dungeness crab, Cancer magister. Biol Bull (Woods Hole) 182:270-277

Carriker MR (1951) Ecological observations on the distribution of oyster larvae in New Jersey estuaries. Ecol Monogr 21:19-38

Clancy M, Epifanio CE (1989) Distribution of crab larvae in relation to tidal fronts in Delaware Bay, USA. Mar Ecol Prog Ser 57:77-82
Cronin TW, Forward RB Jr (1983) Vertical migration rhythms of newly hatched larvae of the estuarine crab, Rhithropanopeus harrisii. Biol Bull Mar Biol Lab Woods Hole 165:139-153

Davis RE, Dufour JE, Parks GJ, Perkins MR (1982) Two inexpensive current-following drifters. Scripps Inst Oceanogr, La Jolla, reference no. $82-28$

De Vries MC, Tankersley RA, Forward RB, Kirby-Smith WW. Luettich RA (1994) Abundance of estuarine crab larvae is associated with tidal hydrologic variables. Mar Biol 118: $403-413$

Eggleston DB, Armstrong DA (1995) Pre-and post-settlement determinants of estuarine Dungeness crab recruitment. Ecol Monogr 65:193-216

Epifanio CE (1987) The role of tidal fronts in maintaining patches of brachyuran zoeae in estuarine waters. $J$ Crustac Biol 7:513-517

Epifanio CE, Valenti CC, Pembroke AE (1984) Dispersal and recruitment of blue crab larvae in the Delaware Bay. Estuar Coast Shelf Sci 18:1-12

Farrell TM, Bracher D, Roughgarden J (1991) Cross-shelf transport causes recruitment to intertidal populations in central California. Limnol Oceanogr 36:279-288

Fernandez MO, Iribarne O, Armstrong DA (1994) Swimming behavior of Dungeness crab, Cancer magister Dana megalopae in still and moving water. Estuaries 17:282-286

Franks PJS, Anderson. DM (1992) Alongshore transport of a toxic phytoplankton bloom in a buoyant current: Alexandrium tamarense in the Gulf of Maine. Mar Biol 112: $153-164$

Graham WM (1993) Spatio-temporal scale assessment of an 'upwelling shadow' in Northern Monterey Bay, California. Estuaries 16:83-91

Gunderson DR, Armstrong DA, Shi Y, McConnaughey RA. (1990) Patterns of estuarine use by juvenile English sole (Parophrys vetulus) and Dungeness crab (Cancer magister). Estuaries 13:59-71

Hobbs RC, Botsford LW (1992) Diel vertical migration and timing of metamorphosis of larvae of the Dungeness crab Cancer magister. Mar Biol 112:417-428

Interactive Data Language User's Guide (1995) Research Systems Inc, Boulder, $\mathrm{CO}$

Kingsford MJ (1993) Biotic and abiotic structure in the pelagic environment: importance to small fishes. Bull Mar Sci 53: 393-415

Kingsford MJ, Choat JH (1986) The influence of surface slicks on the distribution and onshore movement of small fish. Mar Biol 91:161-171

Kingsford MJ, Suthers IM (1994) Dynamic estuarine plumes and fronts: importance to small fish and plankton in coastal waters of NSW. Australia. Cont Shelf Res 14:655-672

Kingsford MJ, Wolanski E, Choat JH (1991) Influence of tidally induced fronts and Langmuir circulations on distribution and movements of presettlement fishes around a coral reef. Mar Biol 109:167-180

Knauss JA (1978) Introduction to physical oceanography. Prentice-Hall, Inc, Englewood Cliffs, NJ

Largier JL (1992) Tidal intrusion fronts. Estuaries 15:26-39

Largier JL (1993) Estuarine fronts - how important are they? Estuaries 16:1-11

Lough RG (1976) Larval dynamics of the Dungeness crab, Cancer magister, off the central Oregon coast, 1970-71. Fish Bull US 74:353-376

McConnaughey RA, Armstrong DA, Hickey BA, Gunderson DR (1992) Juvenile Dungeness crab (Cancer magister) recruitment variability and oceanic transport during the pelagic larval phase. Can J Fish Aquat Sci 49:2028-2044 
Nunes RA, Simpson JH (1985) Axial convergence in a wellmixed estuary. Estuar Coast Shelf Sci 20:637-649

O'Donnell J (1993) Surface fronts in estuaries: a review. Estuaries $16: 12-39$

Olmi EJ Jr (1994) Vertical migration of blue crab Callinectes sapidus megalopae: implications for transport in estuaries. Mar Ecol Prog Ser 113:39-54

Pickney J, Dunstan P (1990) Ebb-tidal fronts in Charleston Harbor, South Carolina: physical and biological characterization. Estuaries: 13:1-7

Pineda J (1994) Internal tidal bores in the nearshore: warmwater fronts, seaward gravity currents and the onshore transport of neustonic larvae. J Mar Res 52:427-458

Poole RL (1966) A description of laboratory-reared zoea of Cancer magister Dana and megalopae taken under natural conditions (Decapodae: Brachyura). Crustaceana 11 $83-97$

Reilly PN (1983) Dynamics of Dungeness crab, Cancer magister larvae off central and northern California. In: Wild PW, Tasto RN (eds) Life history, environment, and mariculture studies of the Dungeness crab, Cancer magister, with emphasis on the central California fishery resource. Calif Dep Fish Game Fish Bull 172:57-84

Editorial responsibility: Otto Kinne (Editor), Oldendorf/Luhe, Germany
Roughgarden J, Gaines S, Possingham H (1988) Recruitment dynamics and complex life cycles. Science 241:1460-1466 Sandifer PA (1975) The role of pelagic larvae in recruitment of populations of adult decapod crustaceans in the York River estuary and adjacent lower Chesapeake Bay, Virginia. Estuar Coast Shelf Sci 3:269-279

Shanks AL (1983) Surface slicks associated with tidally forced internal waves may transport pelagic larvae of benthic invertebrates and fishes shoreward. Mar Ecol Prog Ser 13: $311-315$

Shanks AL (1986) Vertical migration and cross-shelf dispersal of larval Cancer spp. and Randallia ornata (Crustacea: Brachyura) off the coast of southern California. Mar Biol 92:189-199

Shanks AL, Wright WG (1987) Internal-wave-mediated shoreward transport of cyprids, megalopae, and gammarids and correlated longshore differences in the settling rate of intertidal barnacles. J Exp Mar Biol Ecol 114:1-13

Sulkin SD (1984) Behavioral basis for depth regulation in larvae of brachyuran crabs. Mar Ecol Prog Ser 15:181-205

Zeldis JR, Jillett JB (1982) Aggregation of pelagic Munidia gregaria (Fabricius) (Decapoda, Anomura) by coastal fronts and internal waves. J Plankton Res 4:839-857

Submitted: September 5, 1997; Accepted: January 7, 1998

Proofs received from author(s): March 9, 1998 